https://helda.helsinki.fi

\title{
iPads in medical language courses at the University of Helsinki
}

\section{Wallinheimo, Kirsi}

2016-05-04

Wallinheimo , K \& Pitkänen , K K 2016 , ' iPads in medical language courses at the

University of Helsinki ' , Language Learning in Higher Education , vol. 6 , no. 1 , pp. 77-94 . https://doi.org/10.1515/c

http://hdl.handle.net/10138/231812

https://doi.org/10.1515/cercles-2016-0004

publishedVersion

Downloaded from Helda, University of Helsinki institutional repository.

This is an electronic reprint of the original article.

This reprint may differ from the original in pagination and typographic detail.

Please cite the original version. 


\title{
Kirsi Wallinheimo and Kari K. Pitkänen* iPads in medical language courses at the University of Helsinki
}

DOI 10.1515/cercles-2016-0004

\begin{abstract}
In recent years, the Faculty of Medicine at the University of Helsinki has systematically developed and synchronized its teaching technology, and new iPad-based tools have been an important part of this development. The aim has been to provide the students and teachers in the faculty with synchronized tools that can be used as a basis of a shared platform, with all the materials, tools and applications functioning in exactly the same way on all the equipment used in interaction among the teacher and the students and for teaching medicine and dentistry. As language teachers at the University of Helsinki Language Centre, we have already used Moodle-based platforms and a flipped classroom strategy together with task (TBL) and problem-based learning (PBL) approaches in language teaching. The iPads provided by this faculty have been in active use during the sessions of our courses for medical and dental students. However, we have so far been unaware of how the students use their iPads outside the classroom. This survey-based study aimed at addressing this gap in knowledge by investigating how 75 medical students actually use their iPads especially in learning academic and professional English and Swedish. The results, combined with teacher expertise, will be used to further develop the language courses taught by the Language Centre.
\end{abstract}

Keywords: iPads, flipped classroom, student survey, English, Swedish

\section{Context}

Since autumn 2013, all new students of the Faculty of Medicine at the University of Helsinki (http://www.med.helsinki.fi/english/) have been provided with iPads by the university, and the faculty itself has systematically developed a framework where these can be efficiently used for studying medicine and dentistry.

\footnotetext{
*Corresponding author: Kari K. Pitkänen, University of Helsinki, P.O. Box 4, Language Centre, FI-00014, Helsinki, Finland, E-mail: kari.k.pitkanen@helsinki.fi

Kirsi Wallinheimo, University of Helsinki, P.O. Box 4, Language Centre, Fl-00014, Helsinki, Finland, E-mail: kirsi.wallinheimo@helsinki.fi
} 
This has meant not only acquiring electronic materials, but also providing support in learning how to use these iPads in teaching. The main emphasis has not been on the technology itself but rather on pedagogical development, and the faculty has focused on increasing efficiency and improving the quality of teaching, as well as more general synchronization of the tools and approaches used in teaching.

As a part of its in-house training, the Faculty of Medicine has organised workshops based on first-hand experience in the use of this new iPad-based approach. Masalin (2014; see also Masalin and Vahtivuori-Hänninen 2013) discovered that the students use their iPads for studying medicine practically everywhere, and the web, email, books, medical videos (used for teaching) and computer games appear to be among the most popular ways of using them. Collaborative activities take place on the learning platform Moodle (https://moodle.helsinki.fi/) which is widely used at the University of Helsinki. Our main interest was to extend Masalin's (2014) survey and focus on how medical students use their iPads specifically for studying language and communication skills.

At the University of Helsinki (https://www.helsinki.fi/en), faculties specify language requirements for specific language skills required for the degree, but all faculties in Finland have language requirements for both domestic languages (Finnish and Swedish) and at least one foreign language (typically English). The Language Centre (http://www.helsinki.fi/kksc/english/) is responsible for teaching these language courses according to the faculty-specific degree requirements. The most common combination is native Finnish, Swedish as the other domestic language and English as a foreign language, potentially with additional languages, depending on faculties and individual student interests. Both Swedish and English courses are specifically tailored to the faculties and typically taught to students with relatively high starting levels (CEFR B1-B2 for Swedish, B2-C1 for English). However, even though more generic language skills are high in these languages, the students still have additional needs in specific academic and professional language skills. For all the other foreign languages taught at the Language Centre, the numbers of students are so much lower that no faculty-specific courses are available.

In the past, the language courses taught by the Language Centre in the Faculty of Medicine have been offered in separate study years and integrated with the specific needs the students tend to have in a particular year. In English, the three-credit ECTS package has consisted of three courses: a firstyear course developing confidence and fluency, as well as productive skills and medical vocabulary, mainly through presentations and text-based discussions; a second-year course focusing on seminar and practical writing skills; 
and a final, third- or fourth-year course on issues related to multicultural patient interaction. These courses all require slightly different approaches and activities, and thus differing functionality in the iPads the students have received from the faculty. In the Swedish courses, the written component has usually been completed during the first year and the oral skills component after the clinical phase during the fifth year. In the near future, the language courses will be merged within each language, and the faculty will require all the language courses in English and the second domestic language (Finnish or Swedish) to be completed by the end of the second year. Both in English and Swedish, the courses currently consist of a combination of in-classroom and out-of-classroom activities, so that approximately half of the credits are based on independent work.

Pedagogically, the language courses mainly rely on flipped classroom and task/problem-based approaches, and the aims, approaches, coverage and general development of the language courses are discussed in annual planning meetings between the Language Centre and the Faculty of Medicine. In a flipped classroom, rather than deepening the issues taught by the teacher after the session, the students prepare in advance by, for example, reading materials, watching videos, completing exercises provided by the teacher or searching additional information to be used in class. As Toto and Nguyen (2009) have noted, this approach makes the students more active both during the lessons and outside the classroom. All the materials have already for a long time been provided electronically by using Moodle, and the in-class sessions have focused on productive language skills where the students have used iPads, apps and material provided by both the language teachers and the faculty. In our context, this background material is then used during the sessions for discussions, solving problems and giving presentations (see Section 3.1 below for details.) The aim of all this is to increase interaction and student-centeredness and use the shared time more efficiently for developing productive language skills.

In the past, when the language teachers did not have personal iPads, they merely observed how the students used their iPads in class, but what the students used their iPads for was already to some extent taken into consideration in deciding how the in-class activities, tasks and discussions were arranged. However, once the teachers had their own iPads, it became more interesting to investigate what else the students did and could do with their iPads to develop their language skills, and how language courses in which everybody relies on shared technology could be further developed in line with the more general development strategy of the faculty. Thus, although the focus of our study was on the relationship between language learning and technology that enables the 
traditional classroom to be connected to the resources outside the classroom, as language teachers we were also interested in the pedagogical approaches - and possibilities - behind this technology.

Methodologically, this study combined a survey with teacher observations and reflections, i. e. teacher research, which has been actively promoted at the Language Centre for some time (cf. Lehtonen et al. 2015). This was also the first phase of our action research project which aims at surveying how our pedagogical approaches could be further developed for the future when the number of students with iPads and other portable devices is expected to increase in all language courses. Thus, the next step for us will be to explore the usability and effectiveness of actual iPad use in the language learning process. These results will then be used as a basis for the further development of other language courses and to gain valuable first-hand experience of future classrooms where most students will probably rely on portable devices in their studies.

\section{Aims and research questions}

This article focuses on the variety of ways students use their iPads in developing their language skills and the potential needs they have for new types of language-related electronic resources and materials. The more general aim of this action research was to develop tools for language learning in line with the faculty approaches: integration of content and communicative needs so that language courses become better integrated with the discipline-specific content and communicative needs of the students of medicine and dentistry, and the existing technology is used more efficiently, in a pedagogically motivated way to develop a platform for future courses based on how the students currently use this technology. The specific research questions for this study were: how do the medical students utilise their iPads to support language learning, and how efficiently do they feel the available technology (the combination of Moodle, iPads, various apps and content) is used in teaching language courses.

\section{Using iPads in the context of task- and problem-based learning in flipped classrooms}

In the Faculty of Medicine, students are highly motivated, eager to learn, and the starting level for their language skills tends to be high. This is mainly because of the relatively limited annual student intake and the extremely high popularity of 
medical studies in Finland. The students also understand the value of academic and professional language skills and actively engage with the independent tasks and activities both when taking language courses or completing the language requirements by alternative means (see Siddall and Pitkänen 2011). Their approach supports research (e. g. Toto and Nguyen, 2009), suggesting that students in general who actively participate in their learning are more engaged and experience learning more deeply. In the groups of medical students, the group pressure for learning is high, which further encourages the students to aim higher. Since the socio-cultural prestige of the profession is high and the learning environment both competitive and encouraging, they also try to match (and exceed) expectations instead of just completing their degrees. Thus, there is both internal and external pressure as well as the motivation for being the best. In this context, the task- and problem-based approaches combined with the flipped classroom structure, where the content partially relies on their developing expertise in medicine and dentistry, provides enough individual flexibility for the students to understand that language learning is "their own personal thing" rather than just an institutional requirement. Language is the skill that makes their profession possible, since they will spend a large portion of their time discussing and explaining medical issues and matters of life and death to their patients. To support their development, language teachers need to make rational, well-motivated choices in technology and language teaching methodology and consider the needs and desires of the learner (Motteram and Sharma 2009: 85-86).

In this article, we focus on the relationships between language learning and technology. In order to understand the developments in mobile learning settings, it makes sense to apply constructivist and socio-cultural perspectives. For more on this, see Säljö 2000). Among the key components is the idea that students understand the connections between things and know how to apply the rules they know and have acquired in the right contexts. As Säljö (2000: 130) points out, this refers to the way the individual behaves and has become socialised. In language teaching, the focus is on interaction since it plays an essential role in language use and requires both communication and context-specific social activity. The socio-cultural approach emphasises that language is learnt by using it as an interactive tool in practical, social situations (Säljö 2000: 21-23, 130; Vygotsky 1978: 18-20),

\subsection{The combination of PBL and TBL and the flipped classroom technique}

The approaches used for teaching the language courses in the Faculty of Medicine are based on the combined ideas derived from TBLT and PBL and 
the flipped classroom. As already mentioned, this instructional technique, which is also referred as to "classroom flip" or "inverted classroom", allows the teacher to provide traditional lecture materials in an alternative format outside the classroom (Toto and Nguyen 2009). This has made it possible to use the inclass time for interaction and more communicative activities. Table 1 illustrates the accumulation of tasks during a potential learning cycle. In this cycle, Moodle is used as a platform for the pre-session activities, some in-class activities and post-session continuation.

Table 1: Implementing flipped classroom cycle.

\begin{tabular}{ll}
\hline $\begin{array}{l}\text { Pre-session activities } \\
\text { outside or in the classroom }\end{array}$ & In-class activities \\
& $\begin{array}{l}\text { Post-session } \\
\text { continuation outside } \\
\text { the classroom }\end{array}$ \\
\hline
\end{tabular}

\begin{tabular}{|c|c|c|}
\hline $\begin{array}{l}\text { ding the materials } \\
\text { eparing presentations } \\
\text { lecting and preparing } \\
\text { xts and other materials } \\
\text { the student-based } \\
\text { tivities }\end{array}$ & $\begin{array}{l}\text { /problem-based problem solving, } \\
\text { orting and discussions, assessment of } \\
\text { tents, analysis; use of texts, videos } \\
\text { other material available on iPads and } \\
\text { Moodle } \\
\text { r feedback and discussions on written } \\
\text { ignments }\end{array}$ & $\begin{array}{l}\text { Continuation: } \\
\text { Moodle forums for } \\
\text { discussions and chats, } \\
\text { continuation of tasks, } \\
\text { self-reflection, } \\
\text { individual consultation } \\
\text { sessions with the } \\
\text { teacher }\end{array}$ \\
\hline \multicolumn{3}{|c|}{ Moodle: Course-related independent work and additional tasks with the keys } \\
\hline \multicolumn{3}{|c|}{$\begin{array}{l}\text { Media (YLE Areena, News), movies and series (Netflix, HBL Nordic), e-books (iBooks, Gutenbers } \\
\text { e-libraries), Ted, TedMed, social media (Facebook, Twitter, YouTube), e-mail, iMessages, apps } \\
\text { and databases in Medicine, lectures and lecture courses (iTunes U), electronic journals, } \\
\text { magazines and newspapers (e-thesis, e-journals, e-libraries) }\end{array}$} \\
\hline
\end{tabular}

The pre-session activities are based on materials provided in advance either on Moodle or in the classroom before the next session. These activities mainly consist of reading the materials, watching videos and/or preparing summaries, reviews and presentations, either individually or in small groups. The in-class activities engage the students in different types of group activity. The activities reflect real-world challenges, i. e. the students are asked to construct their own responses based on what they already know about medical sciences. The activities and tasks have been designed in line with the characteristics of PBL, which has a long tradition in medical education at the University of Helsinki and is familiar as a learning and studying technique among the medical students. 
According to Hung et al. (2008: 488), "PBL is underpinned by theories of situated learning, which assume that learning is most effective when it is embedded in authentic tasks that are anchored in everyday contexts". Typical characteristics of PBL are that teaching is student-centred and learning is selfdirected, problem-focused and requires collaboration between students while solving the problem (Hung et al. 2008: 488-489). These are also features of taskbased learning. There are several variants of TBL in communicative language teaching, including collaborative language learning, project-based teaching, content-based teaching, task-supported language teaching, task-based language teaching and action-based teaching (see. e.g. Richards and Rodgers 2001). Several properties characterize communicative language teaching, but in general the main aim is to develop the language skills for various social situations (e. g. Brumfit 1984; Richards and Rodgers 2001: 151-177).

The present study was also partly based on TBLT, which shares several of the properties typical of PBL. In TBLT, activities are based around the completion of a central task (e. g. Richards and Rodgers 2001). A good example is a task used in the English courses in which several groups are required to develop a strategy for eradicating malaria in a particular remote river village. In this task, the students are provided with a wide range of journal and magazine articles, book chapters and video clips that discuss the issue from a variety of viewpoints and are encouraged to find additional texts. The material is provided on Moodle, the electronic learning platform, and the students can use their iPads for reading the material and watching the videos at home or in a library. The students divide the material among themselves, each preparing a summary or a critical review for the in-class session. During the in-class session, the students work in their groups, compiling the background material, discussing the issue, trying to develop a good solution to the shared problem. During these sessions, the iPads are typically used for writing notes and for sharing illustrations. After the group discussion, these groups report and present their solutions; in this case a strategy for eradicating malaria, to the other groups, and the other groups assess the solutions presented. Finally, the class as a whole selects the best approach based on the discussions.

For the post-session, the students are given the possibility of continuing the discussion in Moodle forums, and for some of the activities, such as written assignments, they have individual consultation sessions.

\subsection{Utilising the iPads}

Mobile learning (m-learning) is a relatively new research area, but new devices such as iPads and other tablets with enhanced capabilities have encouraged 
language teachers to explore the use and possibilities of the devices and available apps and to either use them or develop them further. M-learning can be seen as a new area of CALL (computer-assisted language learning) renamed as MALL (mobile-assisted language learning) (see Godwin-Jones 2011; Vavoula and Sharples 2008). Since the use of mobile technology is still relatively new, there is a need for research that explores the use and potential of iPads and similar devices. Chen (2013) has investigated how students used tablet computers to learn English in informal settings outside the classroom and how teachers can foster more effective use of the tablets for independent language learning. Since we are gradually moving from CALL to MALL, there is a clear need for a model for merging traditional ICT and m-learning. As we used Moodle as a virtual classroom, we used a pedagogical model that includes the key categories of ICT use. These categories are pedagogical, instrumental, communicative and collaborative use of ICT (Goldsworthy 1999; Vahtivuori-Hänninen 2005; see Figure 1.)

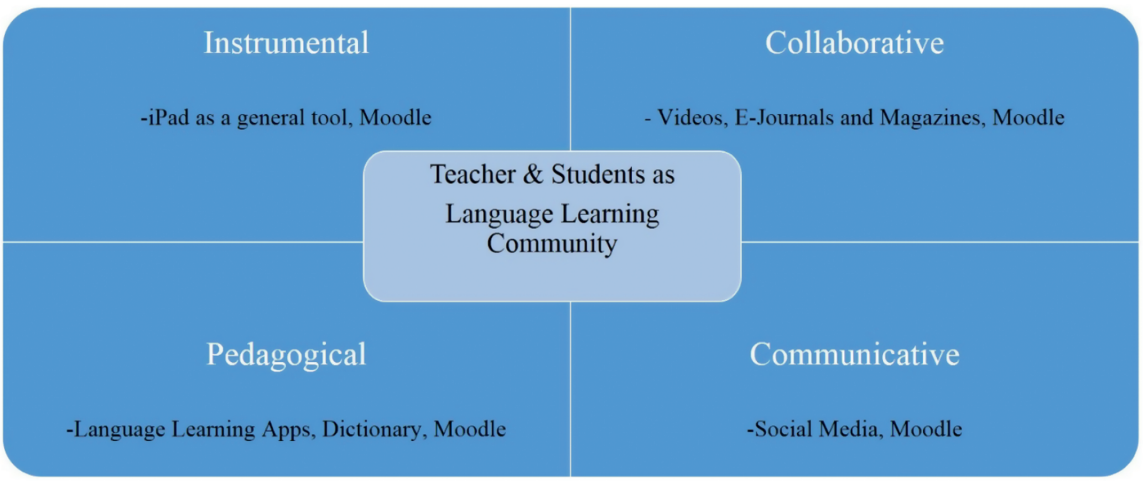

Figure 1: A pedagogical model with the key categories of ICT use.

Figure 1 illustrates how in pedagogical use, learning is facilitated by having content taught using technical equipment or applications. In this study, iPads and the available apps represented instrumental use. In instrumental use, students take full advantage of their iPads and the apps available for learning languages, i. e. they know how to use the technical resources. In communicative use, students learn to interact with one another by using, for instance, shared chat, wiki or Moodle forums. Finally, in collaborative (communal) use, students learn and study together in groups by sharing, negotiating and completing tasks together (Vahtivuori and Masalin 2000: 69-70; Vahtivuori-Hänninen 2005.) A good example would be a shared Prezi (https://prezi.com/) used for a PBL or TBLT activity. 


\section{The survey methods}

Methodologically, this study was based on an electronic survey combined with teacher observations and reflections on teaching development. This electronic survey (e-form) was presented to students of medicine and dentistry while they were taking the faculty-specific English and Swedish language courses provided by the Language Centre at the University of Helsinki. The majority (75 students) completed the survey. As already mentioned, language courses have been integrated with subject studies so that the students are required to complete the English and Swedish courses during the first two years of their studies. In addition, during the clinical phase of their studies, they have an additional advanced-level course on intercultural patient interaction in English. The distribution of students completing the survey reflected this structure (first year $57.33 \%$; second year - $16 \%$; third year - $21.33 \%$; fourth year - no students; fifth year $-5.33 \%$ ). This means that students completing the language requirements by other means were excluded from the survey. These other means include, for example, taking PBL courses taught in English or the exemption tests offered as an option for students who feel their language skills are above CEFR level C1 (cf. Siddall and Pitkänen, 2011). In the future, the medical curriculum will be further developed so that the faculty will require all the language courses to be completed within the first two years. At that point, the results of this survey and teacher observations and expertise will be used as a basis for developing new language courses, and the ideas will later be applied to language teaching in other faculties.

The results of the survey were assessed both qualitatively and quantitatively, and the survey itself had questions related to both of these types (see the appendix for the original Finnish version of the e-form). The survey focused on: a. The frequency of use of iPads in language studies.

b. The types of use of the iPad (dictionary; watching videos, listening activities; reading electronic newspapers, magazines and journals; communication in social media; using language apps; other ways of using the iPad as language support or in language learning).

c. How students wanted to use iPads in language teaching.

d. Other issues that supported language learning during the course.

The distribution of quantitative data and the answers to the open questions were then contrasted with teachers' reflections on the approaches used, and this was used as a basis for reconsidering the future development of these courses. 


\section{The results of the survey}

Figure 1 can be extended by relating the findings of this study to various technological approaches to facilitating learning (Figure 2). The traditional communicative functions, including e-mails and blogs, are still important, but there has been a dramatic increase and development of other functions in recent years. In particular, the use of mobile devices such as iPads, tablets and smart-phones has triggered new needs, and software developers have actively created software and apps to fill the void (and occasionally also created new needs). However, for students (and many other people), the main function still is and will be keeping in touch with others and searching for and modifying various types of content.

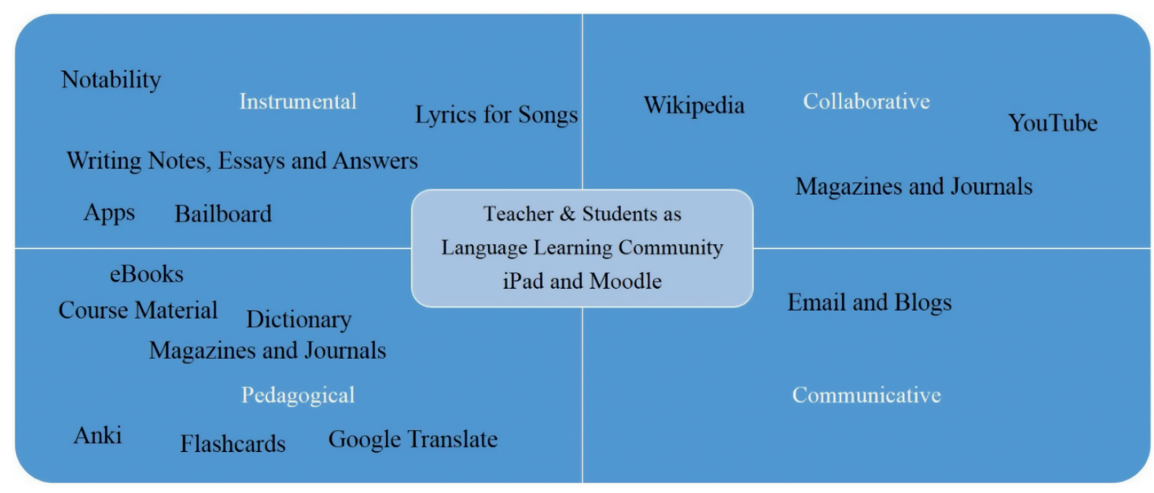

Figure 2: Technological approaches facilitating learning in a language-learning community.

\subsection{The actual use of iPads among the students}

The results presented here are based on our observations of what the students use the iPads for during the in-class sessions of Swedish and English language courses and the results of the survey asking the students about their use of the devices and their wishes for future courses.

There are several possibilities for using iPads or other tablets in language teaching (and related activities). Typical examples include preparing tasks at home, using social media, e-mail, journals and course books, writing notes during contact sessions, and annotating the PDF files provided by the teachers.

According to the results of this survey, the students who owned an iPad used it actively in their studies. Only very few students (12\%) said they never used them. Many of these were older students who were not provided with iPads by the faculty and who took the course later than the others (there were no fourth-year students 
and only four fifth-year students in the sample). Otherwise, almost $88 \%$ of the students reported using them regularly (approximately 69\% every week, 19\% daily). Table 2 shows the main resources the iPads were used for:

Table 2: Distribution of iPad resources used by the students.

\begin{tabular}{lrrrrr}
\hline & Dictionary & Videos & $\begin{array}{r}\text { E-journals } \\
\text { and magazines }\end{array}$ & Social media & $\begin{array}{r}\text { Language } \\
\text { learning apps }\end{array}$ \\
\hline 1st year (43) & $40(93 \%)$ & $19(44 \%)$ & $18(42 \%)$ & $23(54 \%)$ & $2(5 \%)$ \\
2nd year (12) & $10(90 \%)$ & $9(75 \%)$ & $4(33 \%)$ & $6(50 \%)$ & $3(25 \%)$ \\
3rd year (16) & $15(93 \%)$ & $6(37 \%)$ & $2(12 \%)$ & $4(25 \%)$ & $5(31 \%)$ \\
5th year (4) & $2(50 \%)$ & $3(75 \%)$ & $0(0 \%)$ & $1(25 \%)$ & $1(25 \%)$ \\
ALL (75) & $67(89 \%)$ & $37(49 \%)$ & $24(32 \%)$ & $34(45 \%)$ & $11(15 \%)$ \\
\hline
\end{tabular}

Even though these data may not be statistically significant since the sample sizes were low, they do indicate some of the emerging tendencies we have also observed as teachers.

As Table 2 illustrates, most students used their iPads mainly as electronic dictionaries. The iPads were also used for numerous other practical purposes such as storing course materials, scheduling, preparing and presenting data and presentations, functions that they take for granted and that thus were not mentioned in the survey.

In the presentations, for instance on human anatomy, some of the students used their iPads rather than printed notes as a memory aid and presented the visuals on slides. Together with Apple TV, it would also be possible for the students to project content from their iPads directly onto the projector screen.

Another relatively common way of using iPads was for watching videos. However, in the e-form (see Appendix), we did not ask the students to specify whether this meant watching medical videos, TED talks, YouTube videos relevant to their studies, or whether they focused on more commercial distributors of films and television series (on e. g. Viaplay or Netflix). In all cases, this activity could be considered as a tool for developing their oral skills, especially if they did not read the subtitles in Finnish or Swedish. In the classrooms, it was possible to share videos, and the students could write down notes during the talks, discussions and presentations to be used later in their group discussions.

It was interesting to note that there was some variety between the cohorts in how they utilised their iPads. A good example is the use of social media, with first-year students being the most active users; the rates of use then gradually decreased among students in later years. This could indicate that the younger 
generations are more familiar with social media, that they still have time for this, or simply that, as newcomers, they use social media to learn to know their fellow students better or simply to ask questions and try to solve problems about their new studies.

Often, the students have been given tasks to solve as groups. In these tasks, individual students have prepared the tasks or read different materials in advance to be shared with the rest of the group during the in-class session. In these discussions, iPads were used for sharing information, to show and tell about the additional material or resources students had found to be relevant to the task, and in the meeting-type discussions themselves for the secretarial functions of taking notes and presenting the results of group discussions.

One surprise emerged with e-journals and magazines. Even though the university library has gradually increased the number of e-publications, and iPads are a good tool for reading them, the students have clearly not found ejournals and magazines as useful as we might have expected.

The most problematic area was that of language learning apps. Based on the survey results, the older students appeared to start using them later in their studies, but the main problem for the students was to find apps that would actually support the development of their language learning skills in professional and academic contexts and be demanding enough in relation to their starting level (B1-B2 in Swedish and B2-C1 in English). It appears that most apps are designed for levels lower than those of our students, or they require the students to fill in the content (such as in quiz-type vocabulary apps that can be used for memorising jargon and technical terms in two or more languages). Clearly, there is a need to develop more advanced-level materials for this function and/or share the materials already available.

\subsection{Some observations, student wishes and further development}

The results of this study are consistent with those of Masalin (2014). Moodle is used for collaborative activities, and this function will gradually increase since students are encouraged to use Moodle together with the flipped classroom approach to prepare for the tasks to be discussed later. Our results indicate that the students mainly choose apps that help them to memorize technical terms and other lexicon, while, for example, the use of game or simulation elements (which in general are popular among younger generations) or the use of interactive apps designed for language learning has not increased. This could be a result of the limited availability of these apps or it could simply indicate 
that students may not know what is available or how useful these apps might be. They may not have enough time to explore the possibilities outside the main scope of their studies, i. e. medicine and dentistry.

Our study indicates that the attitudes of medical and dental students towards the pedagogical use of iPads were quite positive, which is in line with earlier MALL studies (e.g. Chen 2013). In the classrooms, the students have already adopted the tools and apps developed for group activities. They already know how to share notes and materials in group discussions and seem to be using their iPads not only for acquiring and sharing materials but as a social and communicative tool as well, for example, when preparing their presentations. However, the students do not use all the potential the devices offer, partly because they do not know how, and partly because there are currently not enough specific apps, tools and resources to help them develop their language skills. This problem is even more pronounced for languages other than English.

In the e-form, there was an open question about the hopes and wishes the students have for future language courses. For example, since students of medicine and dentistry are highly motivated and used to working independently, the idea of additional home assignments emerged in the surveys. In addition, they wanted traditional PDF files containing materials and exercises to be replaced by more functional, interactive tasks and exercises. The students also wanted more independent quiz-type activities, for which apps are already available. In general, the students felt that more good apps should be developed for language learning.

The issues brought up by the students indicate that they were motivated, that they clearly wanted to develop their language skills further, also independently outside the classroom, and that they had a clear idea of what types of activities could be developed further. However, they need their teachers to point them in the right direction by providing them with the tools to work with. A good example of this was providing links to online dictionaries (like WordNet), magazines and medical journals that are available electronically. First-year students do not know enough about these resources and have problems in choosing the ones that match their skills and needs. The main problem seems to be that students are not familiar enough with what to search for; as a consequence, they need more guidance in finding suitable discipline-specific and also general electronic journals. In the past, when the printed versions of magazines such as New Scientist, Scientific American and National Geographic and journals like Nature and Science, as well as discipline-specific journals like The Lancet and New England Journal of Medicine, were more visibly present in libraries, students were more likely to skim through them and occasionally read some of the articles. With the electronic journals, students may simply hunt for 
specific topics related to the tasks they have been assigned. If this is the case, it may well lead to at least two serious problems in the future. First, their general knowledge of both science and their disciplines will become more limited; and secondly, their academic writing style will develop later and will be more difficult to acquire if they are not familiar with scientific writing as a genre and if they have not developed an idealised analogical model they are supposed to imitate in their writing (cf. Pitkänen et al. 2009).

Another good example of this is the audio materials and videos (e. g. TED https://www.ted.com/; TEDMED - http://www.tedmed.com/; MEDtube - https:// medtube.net/; Clinically Speaking - https://clinicallyspeaking.co.uk) that can support the development of pronunciation and speaking skills, in addition to the content they provide. Some of this material could also be developed locally, such as authentic patient interactions. Legal and practical problems related to privacy and the rights of the patients could be overcome by modifying the material or creating simulations based on the authentic corpora. Since language teachers typically have no direct access to this type of material, the simulations would have to be developed together with medical professionals and content teachers in the medical faculties. Turning these materials into interactive game-like applications would require the additional expertise of programmers and software developers.

\section{Conclusions}

Students in the Faculty of Medicine at the University of Helsinki have responded positively to the use of iPad-based technology. The iPad has become a natural tool, especially for interaction in group activities and for exploiting course-external medical resources. However, there is a clear difference between the students who have been given iPads and those who have not as regards whether or not they find them useful. Not all students are as familiar with digital devices as we might imagine, but at the moment earlier student cohorts are helping future cohorts of medical students by sharing and transferring their tacit knowledge, and there is both rapid development and increasing the use of mobile learning and teaching technology. The students also use technology actively, but in a relatively limited way. For example, the communicative use of tablets is not as common as we expected. Thus, there is a clear need to develop course materials, pedagogical approaches and additional resources for independent studies. In developing material for task- and problem-based learning, it is essential to know what is currently available for the students of medicine in general, and how useful the applications, iBooks, e-lectures and other resources are, as well as how to use them more 
innovatively and efficiently in language studies. It is also important to develop more authentic tasks and problems so that students can use the combination of language materials in Moodle and their own discipline-specific material to solve tasks and problems interactively in groups, in the same way as they will do in the future as medical professionals.

We language teachers should take a more active role in guiding our students towards those resources (e.g. apps and games) that we know can support their language learning. This could be improved by developing the Moodle learning platforms further by providing more task- and domain-specific links and electronic resources (e-publications, lexical tools like WordNet, etc.), linking the activities to the apps that support task-specific learning and integrating language course activities better with content teaching (databases and electronic course books and other materials).

Students themselves should play a more active role in planning course content, and the questionnaire used for this study could be used to assess how familiar students are with the tools and resources available. Also, the apps, tools and resources available should be shared more efficiently in the future, for example, by using the wiki in Moodle. Some of the apps could also be further developed together with the students. Naturally, the teacher would still have an important role to play in connecting the content, tools and resources to the needs the students have in their language development.

In future, increasing numbers of students will carry various types of sophisticated portable devices. Thus, the results and experience that our project yielded could be used as a platform for developing other language courses aimed at students with a starting level above CEFR B1. More frequent use of portable devices in real-life communication will also become a reality in the future, when doctors use tablet-like devices to consult their patients and present the results of medical examination.

\section{References}

Brumfit, Christopher. 1984. Communicative methodology in language teaching: The roles of fluency and accuracy. Cambridge: Cambridge University Press.

Chen, Xiao-Bin. 2013. Tablets for informal language learning: Student usage and attitudes. Language Learning \& Technology 17(1). 20-36. http://llt.msu.edu/issues/february2013/ chenxb.pdf (accessed 28 August 2015).

Godwin-Jones, Robert. 2011. Emerging technologies: Mobile apps for language learning. Language Learning \& Technology 15(2). 2-11. http://www.llt.msu.edu/issues/june2011/ emerging.pdf (accessed 28 August 2015). 
Goldsworthy, Richard. 1999. Lenses of learning and technology: Roles and opportunities for design and development. Educational Technology 39(4). 59-62.

Hung, Woei, David H. Jonassen \& Rude Liu. 2008. Problem-based learning. In J. Michael Spector, Jeroen G. van Mërrienboer, M. David Merrill \& Marcy P. Driscoll (eds.), Handbook of research on educational communications and technology, 3rd edn, 485-506. Mahwah, NJ: Erlbaum.

Lehtonen, Tuula, Kari Pitkänen \& Johanna Vaattovaara. 2015. Encouraging teacher research through in-house activities: The approach of a Finnish university language centre. In Simon Borg \& Hugo Santiago Sanchez (eds.), International perspectives on teacher research, 170-184. New York: Palgrave Macmillan.

Masalin, Teemu. 2014. iPad ja opiskelijakokemukset. Paper presented at Verkot veteen workshop. http://blogs.helsinki.fi/medi-peda/files/2012/07/IT-Medi-esitys2013.pdf (accessed 28 August 2015).

Masalin, Teemu \& Sanna Vahtivuori-Hänninen. 2013. iPad lääketieteen opettajien työvälineenä. Paper presented at Kasvatustieteen päivät, Jyväskylä, 21 November.

Motteram, Gary \& Pete Sharma. 2009. Blending learning in a Web 2.0 world. International Journal of Emerging Technologies \& Society 7(2). 83-96.

Pitkänen, Kari, Roy Siddall, Tuula Lehtonen \& Anu Virkkunen-Fullenwider. 2009. Analogical models in student writing: Problems of mismatch in the acquisition of writing skills. In Jean-Marc Defays, Annick Englebert, Marie-Christine Pollet, Laurence Rosier \& Francine Thyrion (eds.). Acteurs et contextes des discours universitaires (Actes du Colloque international "Les discours universitaires: formes, pratiques, mutations", Bruxelles, 24-26 avril 2008), 75-87. Paris: L'Harmattan.

Richards, Jack C. \& Theodore S. Rodgers. 2001. Approaches and methods in language teaching. Cambridge: Cambridge University Press.

Siddall, Roy \& Kari K. Pitkänen. 2011. English by alternative means in the Faculty of Medicine. In Pitkänen, Kari K., Jaana Jokinen, Sinikka Karjalainen, Leena Karlsson, Tuula Lehtonen, Mirjami Matilainen, Christian Niedling and Roy Siddall (eds.), Out-of-classroom language learning, 23-38. Helsinki: University of Helsinki Language Centre Publications 2. https://helda.helsinki.fi/handle/10138/25854 (accessed 28 August 2015).

Säljö, Roger. 2000. Lärande i praktiken: Ett sociokulturellt perspektiv. Stockholm: Nordsteds akademiska.

Toto, Roxanne \& Hien Nguyen. 2009. Flipping the work design in an industrial engineering course. Paper given at the 39th ASEE/IEEE Frontiers in Education Conference, T4F2, October 18-21, 2009, San Antonio.

Vahtivuori, Sanna \& Teemu Masalin. 2000. Designing communal Web-based learning environments: Case Globe project. In Seppo Tella (ed.), Media, mediation, time and communication: Emphasis in network-based media education (Media Education Publication 9), 59-82. Helsinki: Department of Teacher Education, University of Helsinki.

Vahtivuori-Hänninen, Sanna. 2005. Pedagogical models in network-based education. In Paul Nicholson, J. Barrie Thompson, Mikko Ruohonen \& Jari Multisilta (eds.), E-training practices for professional organisations, 29-36. London: Kluwer.

Vavoula, Giasemi N. \& Mike Sharples. 2008. Challenges in evaluating mobile learning. Proceedings in Mlearning2008. https://www2.le.ac.uk/Members/gv18/downloads/publicationpreprints/ conference-proceedings/VavoulaSharples-mlearn2008.pdf (accessed 28 October 2015).

Vygotsky, Lev S. 1978. Mind in society. Cambridge, MA: Harvard University Press. 


\section{Appendix}

\section{Kysely iPadin käytöstä kieltenopiskelussa}

vastaa kysymyksiin tai rastita oikea vaihtoehto, joka vastaa parhaiten käsitystäsi.

Täyttämällä Iomakkeen, annan luvan käytāä tietoja tutkimustarkoituksiin kieitenopetuksen kehittämiseksi.

1.

Minkä vuosikurssin opiskelija olet? 1 . vuosikurssi

3.

Käytän iPadia kieltenopiskeluun

en koskaan viikottain päivittäin

Valitse sopiva vaihtoehto $\quad 0 \quad 0$

4.

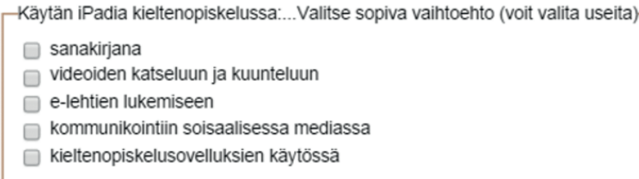

Käytän iPadia jollain muulla tavalla kieltenopiskelussa. Kerro miten ja/tai mitä sovelluksia käytät.

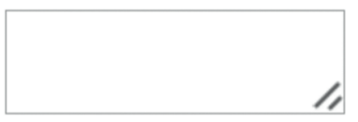

5.

Miten toivoisit, että iPadia käytettäisiin kieltenopetuksessa?

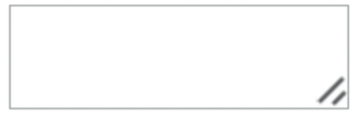

6.

Mikä tällä kurssilla tuki opiskeluasi?

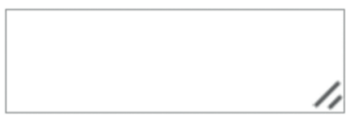

7

Terveisiä kurssin opettajalle:

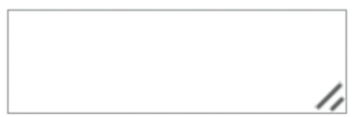

Tietojen lähetys

Tallenna

Kiitos vastauksestasi. 


\section{Bionotes}

\section{Kirsi Wallinheimo}

Kirsi Wallinheimo (MA in Nordic Languages) University Lecturer in Swedish at the University of Helsinki Language Centre since 2003. Her pedagogical and research interests include the implementation of web-based learning environments in language teaching and learning, blended learning and subject teacher education. Currently, she also teaches Swedish academic and professional language skills, especially to the students of medicine and natural sciences. She is also an author of several textbooks in Swedish for Specific Purposes.

\section{Kari K. Pitkänen}

Kari Pitkänen (PhD in General Linguistics), University Lecturer in English at the University of Helsinki Language Centre. His main areas of expertise include linguistics, academic writing and teaching English academic and professional language skills as a foreign language to students of biosciences, medicine, dentistry, agriculture and forestry. His doctoral dissertation (2003) focused on spatio-temporal settings in written narrative fiction. 